\title{
Financial Assessment of Forest Management Systems in the Community Forests: A Case Study from the Midhills of Nepal
}

\author{
Bijendra Basnyat $\mathbb{D}^{1,2}$ \\ ${ }^{1}$ Institute of Forestry, Hariyo Kharka, Pokhara 33700, Nepal \\ ${ }^{2}$ Department of Food and Resource Economics, Faculty of Science, University of Copenhagen, Rolighedsvej 25, \\ DK-1958 Frederiksberg Center, Copenhagen, Denmark
}

Correspondence should be addressed to Bijendra Basnyat; bbasnyat@yahoo.com

Received 30 November 2019; Revised 7 July 2020; Accepted 15 July 2020; Published 25 August 2020

Academic Editor: Anna Zróbek-Sokolnik

Copyright (c) 2020 Bijendra Basnyat. This is an open access article distributed under the Creative Commons Attribution License, which permits unrestricted use, distribution, and reproduction in any medium, provided the original work is properly cited.

In Nepal, forest management priority is shifting to scientific management from conventional management. Though, the forest officials claims that scientific management is beneficial to the forest user groups, comparative financial assessment with conventional management remains unexplored. Following a case study approach, this study compares financial efficiency of two forest management systems in the community forests, focusing on benefit-cost ratio. The study conducted documents review, focus group discussions, and rapid survey to quantify costs and benefits from each forest management system. Conventional management gave a higher benefit-cost ratio to the forest user groups, irrespective of whether forest products are sold at a subsidized price or par with the market price. However, scientific management required high forest management costs and thus had a lower benefit-cost ratio. Sensitivity analysis between two systems revealed that conventional management gave a higher benefit-cost ratio in all cases. The study concludes that forest user groups would bear financial loss if they do not fix the price of the timber at par with the market in scientific management, and in such a case, the tagged price will be beyond affordability of the forest users. Furthermore, scientific management has discouraged kind contribution of users in managing forest. Besides, social and environmental consequences of scientific management cannot be ignored. Hence, the study argues for reconsidering current scientific management considering likely economic and social consequences to the forest user groups.

\section{Introduction}

Scientific forestry involves managing forests based on the "principles of sustained yield" by conducting systematic surveys, developing management plans based on growth statistics, and annual sustained harvesting [1]. German foresters invented scientific forestry in the late eighteenth century for generating revenue from forests, which expanded rapidly across the world during the colonial era [2]. The legacy of this practice still dominates in the era of the present-day participatory forestry, even in the community forests of Nepal $[3,4]$. It has now become a precondition for devolving forest management authority in the global south $[3,5]$.

Nepal is among the first countries to devolve forest management rights to local communities to combat deforestation problems and environmental degradation in the late seventies [6, 7]. The 1993 Forest Act and 1995 Forest Regulation of Nepal recognize community forest user groups as an autonomous institution to conserve, manage, and utilize forests and distribute forest products independently by fixing their prices according to the approved management plan. In 1995, the Community Forest Directive was formulated, which required a simple plan without inventory, integrating forest management rules with the users, allowing them to collect dead, dying, and diseased trees mostly in fallen trees. The focus was largely on tree stand improvement and forest restoration. However, the forest act was amended in 1999, which introduced inventory-based forest management planning in the community forests. In 2000, Community forestry Inventory Guideline was enacted (amended in 2004), which required to estimate the growing stock volume and annual increment in the community 
forests [8]. A certain percentage of annual increment of the growing stock volume was allowed for harvesting, popularly known as annual allowable cut [8]. Growing stock volume of the forests is not depleted in this practice. Although this was the beginning of scientific forestry in Nepal, this system here is considered as the "conventional forest management (ConvFM) system.” This practice maintains constant growing stock volume over a longer period where only increment of the volume of growing stock (tree) is harvested. Furthermore, silviculture operations, such as thinning, pruning, and tree stand improvement, are conducted. However, scholars heavily criticized this practice because of protection-oriented management, limited and unsystematic harvesting of trees, and felling of only superior quality trees [9-11]. Likewise, manipulation of growing stock volume was quite apparent $[12,13]$.

Consequently, the then Ministry of Forests and Soil Conservation of Nepal introduced the new form of forest management practice in 2014, popularly known as "Scientific Forest Management (SciFM)." SciFM is a systematic application of forestry science for the management of forests based on the assessment of attributes of forest crops to maximize and sustain benefits accrued from the forests, following the silvicultural systems [14]. This practice aims to enhance forest productivity, maximize economic returns, and create local-level employment opportunities while improving forest conditions $[14,15]$. Currently, this practice has been implemented in 607 community forests of Nepal, especially in the natural forests with high commercial potential $[15,16]$.

In Nepal, community forestry is not only about commercial forest management but it also linked to rural livelihoods $[11,17]$. The primary purpose of the community forestry is fulfilling the basic need for forest products of local communities and forest restoration, however; the forest users are allowed to sell the surplus in the market [4]. Mostly, the community forests are small patches handed over to user groups for subsistence use, especially for the fodder, firewood, and grasses. More than $52 \%$ of the total community forests of the country are less than 50 ha [18]. In addition, introduction of SciFM in community forests has decreased the cohesion between forest users and forest resources because forest users cannot afford expensive forest management costs [4]. The government often introduced new policy reforms to generate profit from forest resources at the expense of the local communities [19]. In this case, SciFM encourages forest user groups to produce timber at commercial ends, which ultimately generates revenue for the state [4].

Rhetorically, two forms of forest management system exist in the community forests of Nepal, namely ConvFM and SciFM. Scholars argued that SciFM increases revenue from forests and enhances local employment while also improving the forest conditions $[10,20,21]$, but others criticize the system for being highly expensive $[4,17]$. In contrast, ConvFM is financially efficient and gives high returns to the local communities [22-24]. However, there is no comparative assessment of the two forest management systems. A comparative assessment will enable for the efficient use of scarce resources for the benefits of local communities [24, 25]. Hence, financial cost and benefit analysis was conducted to identify the forest management system that is financially beneficial to forest user groups including financial consequences of the SciFM to forest user groups.

\section{Material and Methods}

2.1. Research Case. The study identifies two forest management systems (Table 1). Both systems aim to ensure the sustained yield of the timber and thereby contribute to the local and national economies. However, there exists difference between the two systems.

2.1.1. Conventional Forest Management. ConvFM aims to maintain constant growing stock volume in the forests. The growing stock volume of the forests is not depleted, as only a certain percentage of annual increment of the growing stock volume is harvested. Likewise, limited silvicultural operations such as cleaning of harvesting plots, annual weeding, and forest protection measures are carried out by the user groups.

2.1.2. Scientific Forest Management. SciFM follows a silvicultural system (which is a set of operations applied to forestry crops so that it results in a distinct crop, which is characterized by intensity of felling of trees, pattern of felling, and mode of regeneration) [14]. In this system, forests are divided into different compartments and felling coupes based on the rotation age of the dominant species in the forests. It involves intensive forest management such as tree stand improvements, thinning, singling, and marking and systematic harvesting of marked trees.

2.2. Study Site. The study was carried out in a midhill district of Nepal, which was randomly selected. Of the eight community forests implementing SciFM in the study district, an intensive case study was carried out in two community forests. The community forests were divided into two groups: the first group consisted of community forests with the area less than or equal to $50 \mathrm{ha}$, and second group consisted of community forests with the area above 50 ha. Then, one community forest from each group was randomly selected. The selected community forests were practicing ConvFM until 2013, whereas SciFM was initiated in 2014. Table 2 presents characteristics of the studied community forests. Both community forests (the names of the community forests are arbitrary, and true name is concealed to live up with the promises for ensuring anonymity of studied area) were dominated by natural Sal (Shorea robusta) forests. The forests composed of matured trees, having high commercial potential.

The same community forests were taken as cases for analyzing the financial efficiency of both systems. This would minimize the biases on comparision, since forest conditions 
TABLE 1: Comparison of two forest management systems.

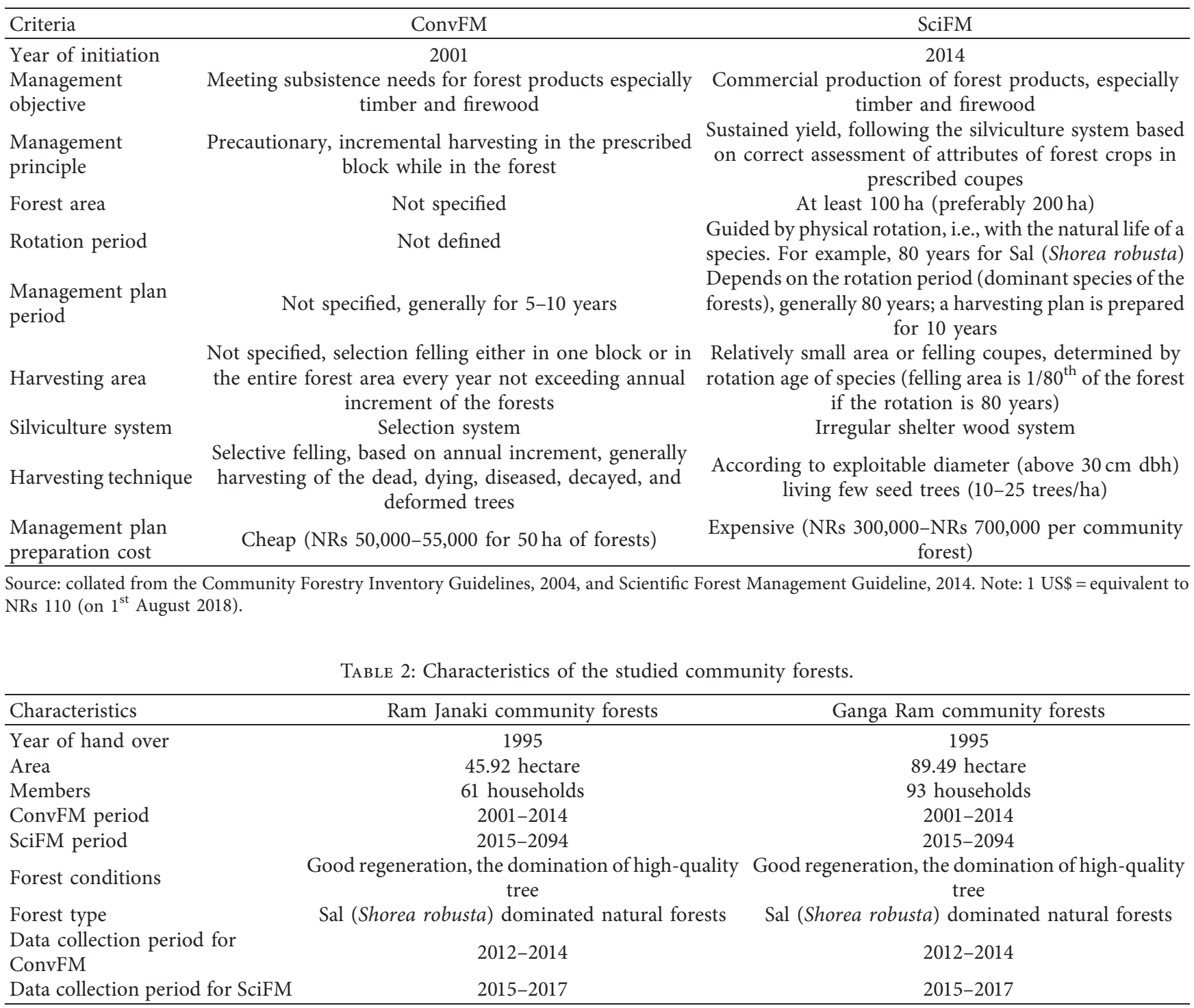

and growing stock volume would vary by forests, which would influence on the benefits and costs.

Both community forests were adopting ConvFM before SciFM. SciFM started in 2015 in both community forests. Data were collected for last three years for each forest management system. Hence, data on SciFM were collected from 2015-2017, whereas that for ConvFM, were collected before the implementation of SciFM, i.e.,(2012-2014).

2.3. Data Collection Methods. The study largely relied on a review of secondary information to quantify the costs and benefits of both forest management systems, followed by focus group discussions/rapid survey and stakeholders' interviews. The study reviewed audit reports and meeting minutes for collecting data for the ConvFM, followed by focus group discussions and rapid survey to quantify the amount and cost of forest products (especially timber) collected under each forest management system. The final cost also included labor contribution. Furthermore, the study relied on recall methods when secondary information was not available. This information was further validated based on interviews. The study conducted a semistructured interview with the forest officials (six persons), timber traders/collectors (five persons), and executive members of the community forests (eight people). The main purpose of these interviews was to validate the study findings. The study also validated the information collected from focus group discussions by reviewing CFUGs records, specifically on forest development expenses, administrative expenses, and harvesting records.

Costs and benefits of forest user groups, including their members, are estimated for the entire duration of the forest management system. The study had fixed the duration of the forest management system of 80 years, based on the rotation age of dominant species i.e., Sal (Shorea robusta). This further coincides with the duration of a SciFM plan period, which is fixed at 80 years. The cost and benefits were annualized and estimated for the per unit area, i.e., NRs/ha. 
2.3.1. Estimation of Benefits. The main priority of the community forests is to fulfill the subsistence needs of forest products of local communities, especially timber, firewood, fodder, and grasses, and sale surplus products in the market. Hence, the study only considered direct use values, such as timber, firewood, fodder, and grasses, for quantification of benefits. Surprisingly, none of the households were collecting non-timber forest products. This is mainly because of unavailability of the non-timber forest product species in the forests. The forests were dominated by the Sal tree, where forest users gave priority timber production. The study did not consider the non-use value such as soil conservation and carbon sequestration, since the purpose of the study was to assess the financial efficiency between the two systems. Nevertheless, the study considered other direct benefits from forests, which include wage employment during management plan preparation, harvesting and logging operations and other community development programs (Table 3 ).

The study conducted a total of six focus group discussions (three in each community forest) with the forest users. More than 72 members participated in the discussions, with whom rapid survey was also carried out. During the discussion, respondents were asked to list the main benefits and then prioritize different benefits from each forest management systems (Table 3). After prioritization, each participant was asked to provide information on the benefits that they received/collected annually from each management system. The benefits include dry firewood, grasses/litters, and other forest products collected from the forests and the number of days of the paid employment from the forest user groups. During the focus group discussions, respondents were asked to specify the prices of firewood, fodder, and grasses, at the local rates.

The study reviewed forest management plans of studied community forests to estimate the annual harvested quantity of forest products, especially timber and firewood. The current (SciFM) plan (2014-2024) estimated the annual growing stock volume and harvestable quantity of the timber and firewood. Hence, the study relied on the growing stock volume of the SciFM. The study computed the annual harvestable quantity in ConvFM following the Community Forestry Inventory Guidelines, 2004. The inventory data of SciFM was used as a reference data. In addition, the study also reviewed the harvesting records of the community forests to compare with the actual harvest. A review of the inventory results of the SciFM in studied community forests revealed that the forest condition falls under "good" category, according to DoF classification [8]. Annual growing stock volume increment of good condition forests for slowgrowing species such as Sal (Shorea robusta) would be 3 percent with allowable harvesting of $75 \%$ of the annual increment [8]. This was used as a basis to estimate the timber and firewood production. In SciFM, timber volume specified in the havesting plan was used to estimate production of timber and green firewood. The study used market price of
2014 to quantify value of the benefits, whereas the users' internal prices for timber and firewood were considered for subsidized prices. The market price of the timber was NRs $1000 / \mathrm{ct}$, whereas subsidized price was only NRs $100 / \mathrm{ct}$. Likewise, market and subsidized price of green firewood per $\mathrm{kg}$ was NRs 10 and NRs 5, respectively. The study also reviewed timber distribution records, membership fees, and meeting minutes, including in-kind labor contributions to estimate the differences between actual practices and official (plan) provisions.

2.3.2. Estimation of Costs. Forest user groups are making cash expenses, largely by mobilizing income received from the sale of the forest products and also making an in-kind contribution, mostly in the form of voluntary labor contribution in both systems. The study considered both kind and cash expenses in estimating costs of each forest management system. Table 4 presents methods followed for estimating the costs. During focus group discussions, forest user groups identified direct cash expenses on forest management such as forest protection (patrolling, fire line construction, and maintenance), silvicultural operations (weeding, thinning, cleaning, pruning, and singling), administrative expense (office operations and management costs such as account keeping, record keeping, stationery expenses, office rent, meeting, and general assembly operations), harvesting and logging expense (tree felling, logging, marking, transport, and depot management), and management plan preparation and revision. Apart from cash expense, they were also making a voluntary labor contribution and participating in meetings. The transaction costs are associated with the opportunity costs of labor of users' participation in the general assembly, meetings, and forest patrolling; in-kind contribution includes voluntary labor for forest management operations such as cleaning, weeding, and forest management operations; and payment of fees such as annual membership and forest product collection fee. Transaction and kind contribution are estimated based on the total number of days spent in different activities, which was then monetized based on the daily local wage rates.

The study reviewed audit report/annual progress report of the studied community forests of the last six years (2012-2017) to compute administrative expenses and forest management expenses. The first three years (2012-2014) of the audit report were used for computation of administrative and forest management costs for ConvFM, whereas later three years (2015-2017) for the SciFM. Likewise, membership fee under each management system was computed based on a review of the records. Besides, harvesting and logging expenses were estimated based on the focus group discussions with the users, which were again validated by interacting with the timber traders.

During focus group discussion, each participant was asked about (a) number of days/hours worked on forestry 
TABLE 3: Methods followed for the estimation of benefits.

\begin{tabular}{lcc}
\hline Benefit & ConvFM & SciFM \\
\hline $\begin{array}{l}\text { Timber } \\
\begin{array}{l}\text { Firewood (green) } \\
\text { Firewood (dry) }\end{array}\end{array}$ & $\begin{array}{c}\text { Computed from the management plan following community } \\
\text { forestry inventory guidelines, 2004 } \\
\text { Fodder (grasses) }\end{array}$ & $\begin{array}{c}\text { Computed from CFUGs harvesting records/ } \\
\text { management plan }\end{array}$ \\
$\begin{array}{l}\text { Wage } \\
\text { (employment) }\end{array}$ & Sale records (2012-2014) & Sale records (2015-2017)
\end{tabular}

TABle 4: Methods followed for the estimation of cost.

\begin{tabular}{|c|c|c|}
\hline Cost & ConvFM & SciFM \\
\hline Forest management & Audit report review (2012-2014)/focus & Audit report review (2015-2017)/focus \\
\hline Administrative & group discussion & group discussion \\
\hline Harvesting and logging & Focus group discussion/traders' interview & Focus group discussion/traders' interview \\
\hline Plan preparation and revision & $\begin{array}{c}\text { Focus group discussion/semistructured } \\
\text { interview }\end{array}$ & Records review/annual progress report \\
\hline $\begin{array}{l}\text { Kind contribution (voluntary labor of forest } \\
\text { user groups) }\end{array}$ & \multicolumn{2}{|c|}{ Rapid survey/focus group discussion } \\
\hline Transaction costs & \multicolumn{2}{|c|}{ Rapid survey/focus group discussion } \\
\hline Membership fee & Records/audit report review (2012-14) & Records/audit report review (2015-17) \\
\hline
\end{tabular}

operations voluntarily, (b) number of days/hours spent for participating in general assembly meetings/executive meeting, (c) days/hours spent to provide advisory support to members/committee, and (d) time spent on management and harvesting plan preparation including office and administrations. Local wage was NRs 800 per day (2018 price), which was used to quantify labor contribution of forest user groups' users on forest management activities. Hence, this cost is additional to cash expenses of forest user groups.

In addition, the study also estimated timber production cost under each management system, which is ratio of total cost required under each management system, (minus value of subsistence benefits) to the total quantity of timber produced.

2.4. Data Analysis. Cost and benefit analysis is a policy assessment method that quantifies the cost and benefits in monetary terms on consequences of public policy [24]. It enables an effective selection of best alternatives for efficient allocation of scarce resources and asesseses impacts of policies in terms of resources they require and effects they produce [26]. This study assumed that forest user groups would get constant benefits and costs over the forest management period (i.e., 80 years) in the absence of information on future cash flows. Following Parajuli et al. [23] and Basnyat [4], the study assumed that initial cost for establishment of community forests is zero, since natural forests were handed over to the users. The study collated annual benefits and costs of three consecutive years for each management system and then annualized according to the management period, i.e., 80 years.

The standard criterion for deciding alternatives is the net present value, which is discounted monetized value of expected net benefits, i.e., benefits minus costs [27]. The present values of the benefits, $\mathrm{PV}(B)$, and costs, $\mathrm{PV}(C)$, are estimated using the equation of Boardman et al. [25].

$$
\mathrm{PV}(C)=\sum_{t=0}^{T} \frac{C t}{(1+i)^{t}} \text { or } \mathrm{PV}(B)=\sum_{t=0}^{T} \frac{B t}{(1+i)^{t}}
$$

where $t$ denotes costs $(C t)$ and benefits $(B t)$ in the year $t$, $\mathrm{i}$ is the discount rate, and $T$ is the time horizon, which is 80 years in our case.

In Nepal, long-term debenture interest rate of the commercial bank is around $10 \%$ per annum, which is used as a discounting rate. Following formula is used to calculate the net present value (NPV) where, decision rule is to adopt policy where NPV is positive and maximum [24]:

$$
\mathrm{NPV}=\mathrm{PV}(B)-\mathrm{PV}(C)
$$

Financial efficiency is assessed using a benefit-cost ratio, which is ratio of present value of benefits to present value of cost. The benefit-cost ratio (BCR) should be higher than one to became finacially efficent, revealing that benefits outweigh the costs. The decision rule is to adopt policy with higher BCR ratio.

$$
\text { Benefit cost ratio }=\frac{\mathrm{PV}(B)}{\mathrm{PV}(C)} \text {. }
$$

The study further conducted a sensitivity analysis to understand the influence of uncertainty in four different situations. The BCR ratio under each scenario is computed, and decision rule is to adopt policy which have higher BCR ratio, under such uncertainaties. Computation of the costs and benefits remains same unless specified.

2.4.1. Market Influence. Market influence is assessed considering discount rate, daily wages and timber price. 
(i) Change in discount rate: discount rate increases from $10 \%$ to $15 \%$ per annum.

(ii) Change in daily wage: increased from NRs 800 to NRs 1000/per day.

(iii) Change in timber price: decreased from NRs 1000/ cft to NRs $700 / \mathrm{cft}$.

2.4.2. Forest User Groups'Behavior in Distributing Timber. Forest user groups are selling subsidized timber to users, which is NRs $100 / \mathrm{cft}$. The study used following assumptions to understand financial efficiency between two systems.

(i) All timber are distributed within the users at the subsidized price.

(ii) Forest user groups distribute half of the timber to the users at a subsidized price and sell the rest at market price.

(iii) Forest user groups distribute three-fourth of the timber to the users at a subsidized price and sell the rest at the market price.

2.4.3. Bureaucratic Behavior in Regulating Timber Harvest. Review of the harvesting records of the community forests reveals that forest officials allowed to harvest $80 \%$ of their annual allowable timber harvest in the ConvFM. However, such proportion is nearly $64 \%$ in SciFM. Hence, the study used following assumptions to analyze the bureaucratic behavior.

(i) Harvesting of $80 \%$ of timber volume specified in the plan.

(ii) Harvesting of $50 \%$ of timber volume specified in the plan.

2.4.4. Fluctuating Annual Benefits and Costs. It might be unrealistic to assume that benefits and costs will remain constant during the forest management plan period. Therefore, study assumed that benefits and costs would increase or decrease by $5 \%$ per annum.

\section{Results}

3.1. Annual Benefits. Five main benefits from the community forests include timber, firewood, fodder, grasses, and wage/employment, which remained similar for both management systems (Table 5). As evident from Table 5, timber and firewood production would be nearly 1.5 times higher in SciFM compared to ConvFM. Also, households were collecting dry firewood (dead branches and fallen trees) for the cooking along with the grasses/litter for the livestock in both system for their subsistence use. During focus group discussions, participants mentioned that the consumption of the firewood, grasses, and litter was a bit higher during the ConvFM plan period. However, their dependency had decreased in recent years. This was mainly because of the shift of households to other sources of energy, especially for the LPG gas and electricity for cooking and decrease in number of livestock and its keeping practices. The increased flow of remittances in the village and out-migration of youth had further decreased direct dependency in the forests.

At the market price, annual benefits from SciFM was NRs 241,798.1/ha, which is almost 1.5 times higher to the ConvFM (NRs 161,521.7/ha). Likewise, SciFM gives higher benefit at subsidized price as well, which is because of high quantity of timber and firewood production. In both forest management systems, timber alone contributed to more than half of the benefits' followed by firewood and grasses. Subsistence benefits such as dry firewood, grasses, and fodder contributed to nearly one-third of the benefits, revealing a high dependency of rural communities on community forests.

3.2. Annual Costs. The cost fluctuates by the forest management system. The review of the records and interactions with the participants revealed the following:

3.2.1. Management Plan Preparation. The SciFM preparation cost was NRs 600,000 for each community forest, in addition to harvesting plan preparation cost of NRs 10,000 per ha for every ten years. The cost was annualized per ha per year, which was NRs 1,110.8 per ha for SciFM. Similarly, ConvFM plan preparation cost was NRs 50,000 for every ten years or NRs 73.8 per ha per year.

3.2.2. Forest Management. This includes direct cash expenses made by forest user groups, such as payment of wages, salary, purchase of equipments, and services. This also includes expenses to reduce dependency on the forests, such as the cooking gas cylinder and electric pole distribution, construction of erosion control measures. The review of the audit reports during ConvFM period (2012-2014) revealed that forest management expenses $23.1 \%$ of their gross income. In case of SciFM, the study reviewed the SciFM plan together with audit reports (2015-2017) to estimate forest management related expenses. According to the plan, forest management expenses are estimated at NRs 60,652.4/ha per year (excluding voluntary labor), whereas audit reports showed a slightly higher expense than the plan provisions with the average expense of NRs 61,543.2/ha per year in the last three years (2015-2017). Forest management cost at the subsidized price would be NRs 17,822.1 per ha in ConvFM, whereas it would be the same for the SciFM.

3.2.3. Harvesting Cost. Interaction with the traders, and review of records reveals that harvesting cost in SciFM and ConvFM was NRs 150/cft and NRs170/cft, respectively. ConvFM has higher cost because harvesting plots are scattered, and thus required more human labor. Harvesting cost would be same for both systems, irrespective of timber selling price within the group or distributed outside.

3.2.4. Administrative Expense. The review of audit reports revealed that administrative expense was $4.0 \%$ of the total income in ConvFM, whereas such proportion was $6.5 \%$ in 
TABle 5: Annual benefits per unit area (ha) by the forest management system.

\begin{tabular}{lccccc}
\hline Items & Unit & Market price (NRs) & \multicolumn{2}{c}{ SciFM } & \multicolumn{2}{c}{ ConvF } \\
& & & Quantity & Value (NRs/ha) & Quantity \\
Value (NRs/ha)
\end{tabular}

SciFM. The high expense on SciFM is mainly because forest user groups' members were traveling to the district headquarters/concerned office frequently to seek support from forest officials. The cost also included administrative expenses for record keeping and auditing.

3.2.5. Kind Contribution (Voluntary Labor). Each user was contributing voluntary labor for forest patrolling, planting, cleaning, and weeding of harvested blocks. Voluntary labor contribution was 22.7 days/ha in SciFM, whereas it was 19.6 days/ha in ConvFM.

3.2.6. Transaction Cost. Time spent on meetings and assemblies was 1.6 and 2.2 labor days per ha per year in ConvFM and SciFM, respectively.

3.2.7. Membership Fee. Users were making annual payment for membership renewal, along with a one-time membership fee. They were also making payments for obtaining permits to collect dry firewood, fodder, litter, and grasses from forests. The membership fee remained same in both projects.

Table 6 compares costs of two forest management systems. Forest user groups were spending NRs 75,768.8 and NRs 118,765.2 per ha per year in ConvFM and SciFM, respectively, when income is generated according to the market price. On the contrary, the cost of ConvFM decreased by almost one-third when forest products were sold at the subsidized price. This is mainly because only a certain proportion of expenses is made on forest management and audit fee in ConvFM. The cost remains almost similar for SciFM since the study assumed that users' expense on forest management would be same, irrespective of the price of timber sold, while adminstrative expense would decrease sightly (Table 6). A larger proportion of the expense was on forest management in both systems, followed by harvesting and voluntary labor contribution.
3.3. Comparative Financial Efficiency. Table 7 compares net present value and benefit-cost ratio at a $10 \%$ discount rate between two systems. When the timber was sold at the market price (NRs $1000 / \mathrm{cft}$ ), the net present value was higher in SciFM, whereas benefits cost ratio was high in ConvFM. This reveals forest user groups got a high return on their investment in ConvFM compared to SciFM, whereas they got higher absolute income in SciFM. On the contrary, forest user groups were distributing timber and firewood at subsidized prices, which is NRs $100 / \mathrm{cft}$ for timber. When this price was used to compute benefits (Table 5) and costs (Table 6), forest user groups would bear a financial loss in the SciFM, whereas the case is completely different in ConvFM (Table 7). Hence, timber price in the SciFM should be at par with the market.

3.4. Timber Production Price. Figure 1 compares costs of timber production between the forest management systems. The costs of timber production in SciFM and ConvFM are NRs $427.3 / \mathrm{ct}$ and NRs $173.4 / \mathrm{cft}$, respectively, while selling price for the users was only NRs $100 / \mathrm{cft}$ only. Users were not aware of the cost of timber production at present and selling timber at a subsidized price, as specified in the plan. Similarly, executive members of both community forests were against the idea of increasing timber prices for internal consumption. In Ram Janaki community forest, forest user groups distributed all the timber within the group, whereas $60 \%$ of the timber was distributed within the group in Ganga Ram community forest, and generated less fund than expected. This reveals that users were distributing timber below the cost of production. They were able to keep the price of timber low because of their voluntary labour contribution during forest management operation.

3.5. Sensitivity Analysis. Sensitivity analysis was carried out in four different scenarios, namely market influences, forest user groups behavior during timber distribution, bureaucratic behavior in regulating timber harvest, and fluctuating 
TABLe 6: Annual costs per unit area (ha) by the forest management system.

\begin{tabular}{|c|c|c|c|c|c|c|c|}
\hline \multirow{2}{*}{ Items } & \multirow{2}{*}{ Unit } & \multicolumn{3}{|c|}{ SciFM (NRs/ha/year) } & \multicolumn{3}{|c|}{ ConvFM (NRs/ha/year) } \\
\hline & & Quantity & Rate (NRs/ha) & Amount & Quantity & Rate (NRs/ha) & Amount \\
\hline \multicolumn{8}{|l|}{ (a) Market price } \\
\hline Plan preparation and revision & ha/year & 1.0 & $1,110.8$ & $1,110.8$ & 1.0 & 73.8 & 73.8 \\
\hline Forest management & ha/year & 1.0 & $60,652.4$ & $60,652.4$ & 1.0 & $37,311.5$ & $37,311.5$ \\
\hline Harvesting and logging & ha/year & 1.0 & $21,298.0$ & $21,298.0$ & 1.0 & $14,875.5$ & $14,875.5$ \\
\hline Administrative & ha/year & 1.0 & $15,716.9$ & $15,716.9$ & 1.0 & $6,460.9$ & $6,460.9$ \\
\hline Kind (labor) contribution & Day/ha/year & 22.7 & 800.0 & $18,188.5$ & 19.6 & 800.0 & $15,711.4$ \\
\hline Transaction costs & Day/ha/year & 2.2 & 800.0 & $1,782.9$ & 1.6 & 800.0 & $1,320.0$ \\
\hline Fees & ha/year & 1.0 & 15.7 & 15.7 & 1.0 & 15.7 & 15.7 \\
\hline Total & & & & $118,765.2$ & & & $75,768.8$ \\
\hline \multicolumn{8}{|l|}{ (b) Subsidized price } \\
\hline Plan preparation and revision & ha/year & 1.0 & $1,110.8$ & $1,110.8$ & 1.0 & 73.8 & 73.8 \\
\hline Forest management & ha/year & 1.0 & $60,652.4$ & $60,652.4$ & 1.0 & $17,822.1$ & $17,822.1$ \\
\hline Harvesting and logging & ha/year & 1.0 & $21,298.0$ & $21,298.0$ & 1.0 & $14,875.5$ & $14,875.5$ \\
\hline Administrative & ha/year & 1.0 & 6041.5 & 6041.5 & 1.0 & $3,086.1$ & $3,086.1$ \\
\hline Kind (labor) contribution & Day/ha/year & 22.7 & 800.0 & $18,188.5$ & 19.6 & 800.0 & $15,711.4$ \\
\hline Transaction costs & Day/ha/year & 2.2 & 800.0 & $1,782.9$ & 1.6 & 800.0 & $1,320.0$ \\
\hline Fees & ha/year & 1.0 & 15.7 & 15.7 & 1.0 & 15.7 & 15.7 \\
\hline Total & & & & $109,089.8$ & & & $52,904.6$ \\
\hline
\end{tabular}

TABLE 7: Financial analysis of two forest management system.

\begin{tabular}{|c|c|c|c|c|}
\hline \multirow{2}{*}{ Present value } & \multicolumn{2}{|c|}{ Market price } & \multicolumn{2}{|c|}{ Subsidized price } \\
\hline & SciFM & ConvFM & SciFM & ConvFM \\
\hline Benefits (a) & $2,658,480$ & $1,775,872$ & 712,581 & 591,490 \\
\hline Cost (b) & $1,319,322$ & 833,470 & 850,464 & 405,768 \\
\hline $\begin{array}{l}\text { Net present value } \\
\text { (a-b) }\end{array}$ & $1,339,159$ & 942,401 & $(134,107)$ & 185,722 \\
\hline $\begin{array}{l}\text { Benefit-cost ratio } \\
(b / a)\end{array}$ & 2.02 & 2.13 & 0.84 & 1.46 \\
\hline
\end{tabular}

Unit: NRs/ha. Note. At 10\% discounting rate.

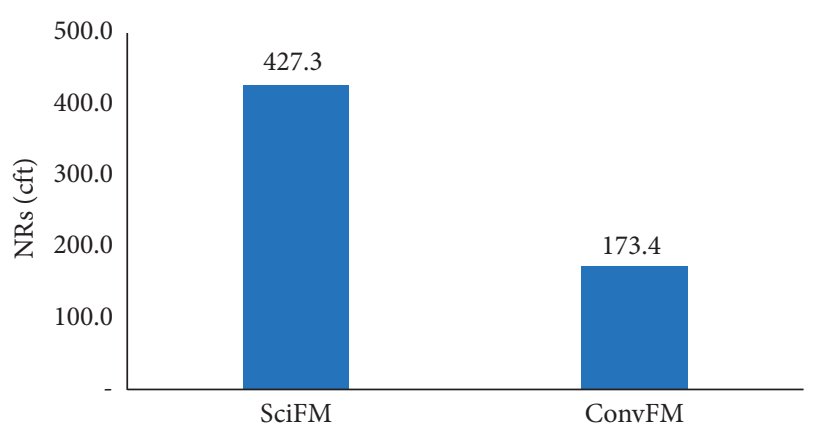

FIgURE 1: Timber production cost in two forest management systems.

annual benefits and costs (Table 8). In all cases, ConvFM gave a higher benefit-cost ratio compared to SciFM.

3.5.1. Market Influence. The market influence was assessed, focusing on changes in the discount rate, daily wage rate, timber price, and all three happened together. The benefitcost ratio was higher in ConvFM in all cases (Table 8). A high benefit-cost ratio revealed that users were getting more return in ConvFM compared to SciFM.
3.5.2. Forest User Groups' Behavior. The forest user groups were distributing more than four-fifths of the timber within the group at the subsidized price, i.e., NRs $100 / \mathrm{cft}$ and selling the rest in the market. If forest user groups distributed all the timber within the group, benefit-cost ratio is less than one in SciFM (Table 8), revealing that it is uneconomic. However, the benefit-cost ratio increases once the proportion of the sale of timber at subsidized timber decreases or vice versa. Nevertheless, benefit-cost ratio was higher in ConvFM compared to SciFM in all cases.

3.5.3. Forest Officials' Behavior in Regulating Harvest. Both ConvFM and SciFM were beneficial to forest user groups, and even harvesting quantity of the timber was reduced. However, benefit-cost ratio was higher in the ConvFM compared to SciFM for both cases (Table 8).

3.5.4. Fluctuations in Benefits and Costs. In constantly changing annual benefits and costs, the benefit-cost ratio was greater than one for both cases, irrespective of the annual changes. However, ConvFM gave a high benefit-cost ratio compared to SciFM (Table 8).

\section{Discussion}

This paper compares financial efficiency of two forest management systems. Between two systems, SciFM is utterly uneconomical to forest user groups, if timber is distributed at subsidized price. It will only be beneficial to forest user groups if they sell forest products, especially timber, at par with the market price. In contrast, net present value is positive in ConvFM, even timber is distributed at subsidized prices. Hence, new management interventions may not necessarily bring additional benefits to the forest user group, which echoes with the findings of Pandey [28] and Karky 
TABLE 8: Sensitivity analysis of two forest management systems.

\begin{tabular}{|c|c|c|}
\hline \multirow{2}{*}{ Particulars } & \multicolumn{2}{|c|}{ Benefit-cost ratio } \\
\hline & SciFM & ConvFM \\
\hline \multicolumn{3}{|l|}{ (a) Market influence } \\
\hline (1) Discounting at $15 \%$ per annum & 2.00 & 2.13 \\
\hline (2) The daily wage of NRs $1000 /$ day & 1.94 & 2.13 \\
\hline (3) Timber price of NRs $700 / \mathrm{ctt}$ & 1.70 & 2.84 \\
\hline (4) All three occurred together & 1.63 & 1.97 \\
\hline \multicolumn{3}{|l|}{ (b) Forest user groups behaviour } \\
\hline (1) All timber sold at a subsidized price (NRs $100 / \mathrm{ct}$ ) & 0.84 & 1.46 \\
\hline (2) Two-thirds of timber sold at a subsidized price $(75 \%)$ and rest in the market price $(25 \%)$ & 1.11 & 1.66 \\
\hline (3) Half of the forest products sold at a subsidized price $(50 \%)$ and rest in the market price $(50 \%)$ & 1.54 & 1.88 \\
\hline \multicolumn{3}{|l|}{ (c) Forest officials' behavior in regulating harvest } \\
\hline (1) $80 \%$ of the volume specified in the plan was allowed for harvesting & 1.81 & 2.10 \\
\hline (2) $50 \%$ of the volume specified in the plan was allowed for harvesting & 1.45 & 2.04 \\
\hline \multicolumn{3}{|l|}{ (d) Fluctuations in benefits and costs } \\
\hline (1) Both cost and benefits increased by $5 \%$ annually & 1.77 & 2.21 \\
\hline (2) Both cost and benefits decreased by $5 \%$ annually & 1.77 & 1.83 \\
\hline
\end{tabular}

Note. At $10 \%$ discounting rate, expect specified.

and Skutsch [29]. The price of the timber influences financial efficiency between two systems.

The cost of timber production in the SciFM and ConvFM is NRs 427.3 and NRs 173.4 per cft, respectively. However, current selling price of the timber is NRs $100 / \mathrm{ctt}$. Hence, forest user groups are distributing timber far below the cost of production. Currently, forest user groups are able to keep the price of timber low because of their voluntary labor (kind) contribution to forest management activities. Voluntary labor contributed to $15.3 \%$ and $20.7 \%$ on the total cost in SciFM and ConvFM respectively. Likewise, forest user groups are distributing timber at subsidized prices as an incentive to kind (voluntary labor) contribution. This echoes with Rai et al. [23] where forest user groups redistributed benefits to their users as compensation for their involvement in community forestry. However, most users during focus group discussions revealed that they are not willing to contribute voluntary labor in both the studied community forests, rather demanding wages for their involvement. This is mainly because of absence of working-age population in the villages and increasing trend of rural to urban migration. In both community forests, nearly half of the households have migrated to urban centers or road head, thus posing challenges in generating voluntary labor contribution. Furthermore, equal distribution of benefits among members irrespective of their participation is discouraging voluntary labour contribution. It will be extremely difficult for users to afford current cost of timber if they do not contribute voluntarily. In contrast, forest user groups should pay internal timber consumption prices to finance expensive SciFM. This may discourage users' participation, since it is contingent upon benefits derived from forests [30].

Currently, forest user groups are not allowed to harvest according to the SciFM plan, thus resulting in fewer benefits. Forest user groups were harvesting only two-thirds of the timber volume specified in the plan. Earlier, ConvFM had faced the same paradox, which was used as a justification for promoting SciFM [31]. However, this trend is now being repeated in SciFM as well. Hence, forest user groups have faced a paradoxical forest administration that promotes SciFM but not allow them to harvest forests according to the SciFM plan [15]. Though cost and benefit analysis had been carried out in SciFM, aiming to justify the economic rationale at the very early stage, this practice had simply remained as a prerequisite in the management planning processes. Neither the forest user groups had received benefits according to the plan nor they had invested accordingly.

Technically, investment shall be made in the management system, which generated a higher net present value [25]. In our case, SciFM generated a higher net present value, revealing that investment is worthwhile. However, investment capacity of the users can not be ignored. The forest user groups are mobilizing their last year income in forestry activities, whereas leveraging of fund and resources from other areas are almost negligible. Likewise, they have neither received financial support nor incentives from the government or from development partners. SciFM requires almost 1.5 times higher investment compared to ConvFM. However, forest user groups are struggling to generate funds according to the plan. They neither conducted a financial need assessment nor identified financing options/financial sources for implementing SciFM plan. They simply relied on the fund generated from the forests and investing according to the gross income of the forests complying with the provisions of 1993 Forest Act. According to the Act, forest user groups shall spend at least $25 \%$ of their gross income on forest development activities. At present, they are spending around $22.5 \%$ on ConvFM and $30.5 \%$ in SciFM. However, this amount is far below in absolute terms when compared with the investment needs envisioned in SciFM. In ConvFM, forests are being managed under "precautionary principle" where constant growing stock volume is maintained; thus, limited expenditure on forest management might not bring adverse environmental risks. On the contrary, SciFM promotes intensive harvesting in the small unit of land, thus creating more environmental risks [15]. The forest management expenditure are mostly used in forest protection, 
especially for paying salary of forest watchers or reducing direct dependency on forests, such as cooking stove distribution and electric pole installation. Infact, this should not be considered as forest management expenses. Sustainability can only be achieved if reinvestments are made in the forest, especially on forest management operations, such as tree stand improvement, silvicultural operations, and restoration [32]. However, reinvestment is very low. In absence of adequate investment capacity of the forest user groups, SciFM risks to forest sustainability.

SciFM was introduced in those community forests, which have commercial potential and high-value forests. Neither area of the forests nor forest conditions were decisive criteria in selection. Likewise, interests of the forest user group or management objective of the forests were never considered. Our analysis reveals that SciFM is beneficial if promoted for commercial purposes, whereas ConvFM for subsistence use. As community forestry was mostly promoted for fulfilling subsistence need of the local communities, relavancy of the SciFM in present context is highly contested. Basnyat [4] considers the SciFM as a means for commodicification of the community forestry in Nepal and raised concern over distributional justice.

Decision-makers should not rely on benefit-cost ratios but, instead, use it as one of the several criteria and discuss relationship between the benefit-cost analysis and any "unquantified environmental impacts," values, and amenities, while making such investment decisions [27]. Among two management systems, SciFM would bring more environmental risks such as landslides and erosion since intensive harvesting was carried out in a small area [15]. In contrast, harvesting area is scattered in ConvFM, thus posing a less environmental risk. In addition, social capital is high and intrigued in the ConvFM, compared to the SciFM. Technically complex management systems have increased dependency of the users with the forest officials. The technical domination in the forest management systems has increased liability of the executive committee to the forest officials, thereby ignoring voices and needs of the local people. Earlier, decisions in the community forests were taken through consensus with deliberative discussions amongst the users; but now, the costly SciFM plans and technical prescriptions are often used to suppress the voices of the people and thereby affecting social cohesions and collective decision-making $[31,33]$. While selecting the forest management system, financial efficiency should be one criterion out of many. Besides, socioeconomic, environmental, and social consequences of the forest management system should be considered. First, the purpose of management, including management objective of the forest user groups, should be considered in selecting an appropriate forest management system, i.e., producing timber to commercial ends or subsistence use or multiple use forestry. Second, financial capacity of the forest user groups, including their investment capacity, should be considered, including arrangment of financial sources for implementing plan (financing options). Finally, economic, environmental, and social consequences should be examined.

\section{Conclusion}

In rhetoric, SciFM is beneficial to forest user groups, since net present value is positive and high compared to ConvFM. However, reality is completely different because benefits are computed at the market price. On the contrary, forest user groups were distributing timber at highly subsidized prices, which is ten times lower than the market price. SciFM may not be beneficial to the forest user groups if they continue to distribute timber at the subsidized price. The forest users were neither aware on the cost of timber production nor were in favour of increasing timber prices to finance SciFM. Likewise, their current investment is far below the investment requirement of the SciFM. Hence, financially efficient SciFM is only a virtual reality. Nevertheless, SciFM can recover the management cost, if one-fourth of the timber is sold at par with the market prices. Hence, SciFM encourages commercialization of community forests. In contrast, ConvFM has not only generated a higher benefit-cost ratio compared to SciFM but also has a positive net present value even when timber was distributed at the subsidized prices. Currenlty, SciFM is justified on economic ground, which included quantity of timber production, fund generation, and employment creation from forests. The selection of forest management system should not only be guided by financial analysis but other factors should be taken into account. In the present situation, ConvFM seems more beneficial considering limited environmental impacts, poor investment capacity of the users, and management of the forests based on the precautionary principle.

In Nepal, most of the community forests are small in size (less than $50 \mathrm{ha}$ ) and largely managed for subsistence use, hence promoting SciFM might not be financially viable nor required [5, 18]. Rather, community forests having high commercial interests should be mapped, and SciFM should be promoted for producing timber for commercial use. This case study shares lesson learned at a local scale on the selection of financially beneficial forest management system. Further work from a larger geographic area with a wider range of community forests is required. Besides, this study conducted a comparative ex-ante cost-benefit analysis between forest management systems and did not look at implementation aspects. The users were neither able to generate benefits as stipulated in the plan nor making investments accordingly. The extraction of forest resources without reinvestment may bring negative biophysical and environmental consequences. Hence, there is a need to examine implementation aspects of each management system.

\section{Data Availability}

The data used to support this study are available from the corresponding author upon request.

\section{Conflicts of Interest}

The author declares that there are no conflicts of interest regarding the publication of this article. 


\section{Acknowledgments}

The author thanks the "Science and Power in Participatory Forestry" (13-05KU) funded by the Consultative Research Committee for Development Research under the Danish Ministry of Foreign Affairs.

\section{References}

[1] R. Guha, "Scientific forestry and social change in Uttarakhand," Economic and Political Weekly, vol. 20, no. 45-47, pp. 1939-1952, 1985.

[2] J. Scott, Seeing like a State: How Certain Schemes to Improve the Human Condition Have Failed, Yale University Press, Cambridge MA, USA, 1998.

[3] J. C. Ribot, Democratic Decentralization of Natural Resources: Institutionalizing Popular Participation, World Resources Institute, Washington, DC, USA, 2002.

[4] B. Basnyat, "Commodifying the community forestry: a case from scientific forestry practices in Western Hills of Nepal," Journal of Forest Research, vol. 25, no. 2, pp. 69-75, 2020.

[5] R. L. Rutt, B. B. K. Chhetri, R. Pokharel, S. Rayamajhi, K. Tiwari, and T. Treue, "The scientific framing of forestry decentralization in Nepal," Forest Policy and Economics, vol. 60, pp. 50-61, 2015.

[6] A. K. Bhattacharya and B. Basnyat, "Decentralisation and community forestry programmes in Nepal: issues and challenges," International Forestry Review, vol. 7, no. 2, pp. 147$155,2005$.

[7] H. R. Ojha, "Beyond the "local community": the evolution of multi-scale politics in Nepal's community forestry regimes," International Forestry Review, vol. 16, no. 3, pp. 339-353, 2014.

[8] Department of Forest, Community Forest Inventory Guideline, 2004. Nepal, Department of Forest, Kathmandu, Nepal, 2004.

[9] V. R. Subdei, I. Poudel, and P. Bhattaria, "Application of silviculture system, yield regulation and thinning in natural forests," in Proceedings of the Silviculture for Forest Management: Proceedings of the First National Silviculture Workshops, Department of Forest, Kathmandu, Nepal, pp. 132-139, February 2017.

[10] P. N. Koirala and K. P. Achayra, "Silviculture evolution: a retrospective review to uncover appropriate lessons for forestry advance in Nepal," in Proceedings of the Silviculture for Forest Management: Proceedings of the First National Silviculture Workshops, Department of Forest, Kathmandu, Nepal, pp. 69-79, February 2017.

[11] S. Baral, B. B. K. Chhetri, H. Baral, and H. Vacik, "Investments in different taxonomies of goods: what should Nepal's community forest user groups prioritize?" Forest Policy and Economics, vol. 100, pp. 24-32, 2019.

[12] V. Iversen, B. Chhetry, P. Francis et al., "High value forests, hidden economies and elite capture: evidence from forest user groups in Nepal's Terai," Ecological Economics, vol. 58, no. 1, pp. 93-107, 2006.

[13] S. Baral, H. Meilby, B. B. Khanal Chettri, B. Basnyat, S. Rayamajhi, and S. Awale, "Politics of getting the numbers right: community forest inventory of Nepal," Forest Policy and Economics, vol. 91, pp. 19-26, 2018.

[14] Ministry of Forest and Soil Conservation, "Scientific forest management guideline, 2014," Nepal: Ministry of Forest and Soil Conservation, Kathmandu, Nepal, 2014.
[15] B. Basnyat, T. Treue, and R. K. Pokharel, "Silvicultural madness: a case from the "Scientific Forestry" initiative in the community forests of Nepal," Banko Janakari, vol. 27, pp. 54-64, 2018.

[16] Ministry of Finance, Economic Survey: Fiscal Year 2019/ 2020, Ministry of Finance, Nepal, Kathmandu, Nepal, 2020, https://mof.gov.np/uploads/document/file/Economic_Survey_ 2076-77.pdf.

[17] J. F. Lund, K. Baral, N. S. Bhandari et al., "Who benefits from taxation of forest products in Nepal's community forests?" Forest Policy and Economics, vol. 38, pp. 119-125, 2014.

[18] Department of Forest, Community Forestry Data Base of Nepal, Nepal: Department of Forest, Kathmandu, Nepal, 2019.

[19] H. Kopnina, "Commodification of natural resources and forest ecosystem services: examining implications for forest protection," Environmental Conservation, vol. 44, no. 1, pp. 24-33, 2017.

[20] Y. Khanal, "Regeneration promotion and income generation through scientific forest management in community forestry," in Proceedings of the Silviculture for Forest Management: Proceedings of the First National Silviculture Workshops, Department of Forest, Kathmandu, Nepal, pp. 132-139, February 2017.

[21] K. C. Poudel, "Silviculture for forest management in Nepal," Banko Janakari, vol. 27, no. 3, pp. 15-20, 2018.

[22] K. C. Anup, I. Koirala, and N. Adhikari, "Cost-benefit analysis of a community forest in Nepal," Journal of Sustainable Forestry, vol. 34, no. 3, pp. 199-213, 2015.

[23] R. Parajuli, D. Lamichhane, and O. Joshi, "Does Nepal's community forestry program improve the rural household economy? a cost-benefit analysis of community forestry user groups in Kaski and Syangja districts of Nepal," Journal of Forest Research, vol. 20, no. 6, pp. 475-483, 2015.

[24] R. Rai, P. Neupane, and A. Dhakal, "Is the contribution of community forest users financially efficient? a household-level benefit-cost analysis of community forest management in Nepal," International Journal of the Commons, vol. 10, no. 1, 2016.

[25] A. E. Boardman, D. H. Greenberg, A. R. Vining, and D. L. Weimer, Cost-benefit Analysis: Concepts and Practice, Cambridge University Press, Cambridge, UK, 2014.

[26] Asian Development Bank, Cost-benefit Analysis for Development: A Practical Guide, Asian Development Bank, Mandaluyong, Philippines, 2013.

[27] J. Talberth, Economic Benefits of Forest Restoration in the Signal Peak Assessment Area, Gila National Forest. Center for Sustainable Economy, Silver City, NM, USA, 2009, http:// sustainable-economy.org/wp-content/uploads/RestorationBenefits-Final1.pdf.

[28] S. S. Pandey, T. N. Maraseni, K. Reardon-Smith, and G. Cockfield, "Analysing foregone costs of communities and carbon benefits in small scale community based forestry practice in Nepal," Land Use Policy, vol. 69, pp. 160-166, 2017.

[29] B. S. Karky and M. Skutsch, "The cost of carbon abatement through community forest management in Nepal Himalaya," Ecological Economics, vol. 69, no. 3, pp. 666-672, 2010.

[30] V. Maskey, T. G. Gebremedhin, and T. J. Dalton, "Social and cultural determinants of collective management of community forest in Nepal," Journal of Forest Economics, vol. 11, no. 4, pp. 261-274, 2006.

[31] B. Basnyat, T. Treue, R. K. Pokharel, S. Baral, and Y. B. Rumba, "Re-centralisation through fake Scientificness: the case of community forestry in Nepal," Forest Policy and Economics, vol. 115, Article ID 102147, 2020. 
[32] S. Baral and H. Vacik, "What governs tree harvesting in community forestry-regulatory instruments or forest bureaucrats' discretion?" Forests, vol. 9, no. 10, p. 649, 2018.

[33] S. Baral, H. Meilby, and B. B. K. Chhetri, "The contested role of management plans in improving forest conditions in Nepal's community forests," International Forestry Review, vol. 21 , no. 1, pp. 37-50, 2019. 